\title{
Hydrogen peroxide regulated salicylic acid- and jasmonic acid-dependent systemic defenses in tomato seedlings
}

\author{
Yun-feng ZHANG ${ }^{1 *}$ (D), Hai-ying $\mathrm{ZHOU}^{1}$, Yu-ling TANG ${ }^{1}$, Yu-ming LUO $^{1}$, Zhu-yi ZHANG ${ }^{1}$
}

\begin{abstract}
To investigate the regulation of hydrogen peroxide $\left(\mathrm{H}_{2} \mathrm{O}_{2}\right)$ in SA- and JA-dependent systemic defense pathways in tomato seedlings damaged by cotton bollworm. The lower two leaves of four-leaf tomato plant seedlings were treated with cotton bollworms. The upper leaves were then removed at various time points and assessed for systemic changes in $\mathrm{H}_{2} \mathrm{O}_{2}$ levels, enzyme activity and defense-related genes expression. Wild-type seedlings, def-5 mutant seedlings (deficient in JA accumulation) and transgenic nah $G$ seedlings(deficient in SA content) were constructed at four-leaf stage. Wild-type plants were further treated with dimethylthiourea (DMTU) and 2,5-dihydroxycinnamic acid methyl ester (DHC). Bollworm feeding in the lower leaves induced rapid systemic accumulation of $\mathrm{H}_{2} \mathrm{O}_{2}$ in the upper leaves. $\mathrm{H}_{2} \mathrm{O}_{2}$ accumulation further increased activities for SA- and JA-dependent enzymes including proteinase inhibitors (PIs), pathogenesis-related gene 1 (PR-1), cathepsin D inhibitor (CDI), $\beta$-1,3-glucanse (BGL) and polyphenol oxidase (PPO). Furthermore, $\mathrm{H}_{2} \mathrm{O}_{2}$ accumulation enhanced mRNA expression of BGL-2, PR-1, PI, CDI and PPO genes. Suppression of $\mathrm{H}_{2} \mathrm{O}_{2}$ accumulation using $\mathrm{H}_{2} \mathrm{O}_{2}$ scavengers substantially diminished these effects. mRNA expression of PR-1 was not induced in transgenic nah $G$ plants. SA- and JA-dependent signaling pathways are involved in the tomato systemic defense responses to herbivores, and that $\mathrm{H}_{2} \mathrm{O}_{2}$ generation is required for both systemic pathways.
\end{abstract}

Keywords: Heliothis armigera; hydrogen peroxide; jasmonic acid; salicylic acid; tomato seedling; defense response.

Practical Application: mRNA expression of PR-1 was not induced in transgenic nah $G$ plants. SA- and JA-dependent signaling pathways are involved in the tomato systemic defense responses to herbivores, and that $\mathrm{H}_{2} \mathrm{O}_{2}$ generation is required for both systemic pathways.

\section{Introduction}

Plants can utilize both constitutive and inducible defense mechanisms to protect themselves against attack from pathogens and herbivores (Schulze et al., 2019; Mason et al., 2017; Mayrose et al., 2004; Chen, 2008; Rasmann \& Agrawal, 2009; Agrawal et al., 2015). Defense responses induced by insects include a local hypersensitivity response and the production of signaling molecules, which then systemically activate defenserelated genes and enzyme pathways generating biomolecules such as toxins, repellents and natural enemy attractants (Smith et al., 2009; Fan et al., 2012). These molecules can harm insects via physiological disruption, inhibition of digestion and assimilation, repel insects or attract their natural enemies (Erb \& Reymond, 2019; War et al., 2012; Fürstenberg-Hägg et al., 2013).

Several signaling molecules, including reactive oxygen species (ROS), salicylic acid (SA), jasmonic acid (JA) and ethylene (ET), have been implicated in these defense responses and work together as a network (Qi et al., 2018; Waterman et al., 2019; Grant \& Lamb, 2006). JA is a synthesized from linolenic acid via the octadecanoid pathway, and is considered to be a key regulator for stress-induced gene expression in all plants (Browse, 2009; Koo \& Howe, 2009). Both mechanical wounding and insect feeding can induce accumulation of JA and increase the activities of proteinase inhibitors (PIs), cathepsin D inhibitor (CDI) and polyphenol oxidase (PPO) in tomato seedlings (Orozco-Cárdenas et al., 2001; Tholl et al., 2011). Plants defective in JA synthesis are

highly susceptible to herbivores (Stotz et al., 2002; Ellis et al., 2002). Similarly, SA-dependent signaling is essential for local hypersensitivity responses and resistance against many plant pathogens (Shine et al., 2019). SA mediates the transcription of $\beta$-1,3-glucanase gene 2 (BGL-2) and pathogenesis-related gene 1 (PR-1) in tobacco seedlings following pathogenic infection. SA treatment also enhances herbivore defense in wheat after aphid feeding (Mohase \& Van der Westhuizen, 2002).

Among ROS produced in plants, hydrogen peroxide $\left(\mathrm{H}_{2} \mathrm{O}_{2}\right)$ is particularly toxic to pathogens, including insects (Zhu-Salzman et al., 2005). $\mathrm{H}_{2} \mathrm{O}_{2}$ is involved in various signal transduction pathways and serves as a signaling molecule, activating defense responses in plants (Sharma et al., 2019; Zurbriggen et al., 2010). JA can induce accumulation of $\mathrm{H}_{2} \mathrm{O}_{2}$ and activation of the octadecanoid pathway in wounded tomato seedlings (Orozco-Cárdenas et al., 2001). In aphid-infested barley, $\mathrm{H}_{2} \mathrm{O}_{2}$ accumulates rapidly and is involved in ET production, suggesting an important role of $\mathrm{H}_{2} \mathrm{O}_{2}$ in defense responses (Argandoña et al., 2001). SA can specifically inhibit the activity of catalase in vitro and cause an increase in $\mathrm{H}_{2} \mathrm{O}_{2}$ concentrations in vivo (Chen et al., 1993). $\mathrm{H}_{2} \mathrm{O}_{2}$ itself induces accumulation of free benzoic acid and SA in tobacco leaves (Qi et al., 2018). SA can suppress the octadecanoid pathway and accumulation of PI-I in JA-treated tomato seedlings (Spoel et al., 2003). 
To date, most of the research in this area has focused on the roles of $\mathrm{H}_{2} \mathrm{O}_{2}, \mathrm{SA}$ and JA in plant defense responses to local pathogen infection or mechanical wounding; however, the molecular mechanism involved in $\mathrm{H}_{2} \mathrm{O}_{2}$ regulation of plant systemic defense responses against infection is not clear. In the present study, we used the cotton bollworm-treated tomato seedlings as a model to determine the contribution of $\mathrm{H}_{2} \mathrm{O}_{2}$, JA and SA signaling to systemic defense responses.

\section{Materials and methods}

\subsection{Tomato seedlings}

Tomato plants (Lycopersicon esculentum cv. Castlemart) were grown in a growth chamber with a photoperiod of $18 \mathrm{~h}$ light $\left[300 \mu \mathrm{E} / \mathrm{m}^{2} / \mathrm{sec}\right]$ at $28{ }^{\circ} \mathrm{C}$, and $6 \mathrm{~h}$ dark at $23^{\circ} \mathrm{C}$. Mutant def-5 plants and transgenic plants expressing $n a h G$ were grown under the same conditions. Seedlings at the four-leaf stage (containing two upper leaves and two lower leaves) were used in all experiments.

\subsection{Cotton bollworm feeding}

Cotton bollworms (Heliothis armigera; Lepidoptera: Noctuidae) were collected in Jingzhou, Hubei Province, China in 2009 and thereafter mass-reared on artificial diets at $26 \pm 1{ }^{\circ} \mathrm{C}$ and $80 \pm 5 \%$ relative humidity with a 14 -h light and 10 -hr dark regime. During experiments, fourth-instar bollworms were placed on the lower (local) leaves of wild-type, mutant and transgenic seedlings. When $80 \%$ of the two lower leaves were consumed (-6 h), the cotton bollworms were removed. Upper (systemic) leaves were harvested at various times ranging from 3 to $37 \mathrm{~h}$ after initiation of feeding, flash-frozen in liquid nitrogen and stored at $-70{ }^{\circ} \mathrm{C}$ until analysis.

\section{$2.3 \mathrm{H}_{2} \mathrm{O}_{2}$ scavenging}

To remove $\mathrm{H}_{2} \mathrm{O}_{2}$, seedlings were watered with the $\mathrm{H}_{2} \mathrm{O}_{2}$ scavengers DMTU $(0.1 \mathrm{mM})$ or DHC $(10 \mu \mathrm{M})$ daily for 3 days prior to treatment with caterpillars (Levine et al., 1994). Tomato leaves were also sprayed with the same solution throughout the experimental period.

\subsection{Measurement of $\mathrm{H}_{2} \mathrm{O}_{2}$ concentration}

Frozen leaves $(0.2 \mathrm{~g})$ were ground to a fine powder in liquid nitrogen and homogenized with $1 \mathrm{~mL}$ of $0.2 \mathrm{M}$ perchloric acid at $4{ }^{\circ} \mathrm{C}$. The extract was kept on ice for $5 \mathrm{~min}$ and then centrifuged at $10,000 \times g$ for $10 \mathrm{~min}$ at $4^{\circ} \mathrm{C}$. Then the supernatant was collected and the concentration of $\mathrm{H}_{2} \mathrm{O}_{2}$ was measured as described by Chen et al. (1993).

\subsection{Enzyme activity assays}

Frozen upper leaves were homogenized in $10 \mathrm{mM}$ Tris- $\mathrm{HCl}$, $\mathrm{pH} 8.0$ to obtain $1 \mathrm{~g}$ leaves (fresh weight, FW) per $5 \mathrm{~mL}$ buffer at $4{ }^{\circ} \mathrm{C}$, and then centrifuged at $12,000 \times g$ for $10 \mathrm{~min}$ at $4{ }^{\circ} \mathrm{C}$. The supernatant was collected for enzyme activity assays at room temperature on a DU800 spectrophotometer (Beckman
Coulter, Inc., CA, USA). All experiments were performed using 3 replicates.

BGL activity was assayed using laminarin (Sigma, St Louis, USA) as the substrate (Fink et al., 1988). Enzyme extract $(100 \mu \mathrm{L})$ was incubated with $0.25 \mathrm{~mL} 10 \mathrm{mM}$ Tris- $\mathrm{HCl}, \mathrm{pH}$ 8.0 , containing $2 \mathrm{mg} / \mathrm{mL}$ laminarin for $30 \mathrm{~min}$ at $37^{\circ} \mathrm{C}$. The absorbance at $550 \mathrm{~nm}$ was monitored over time with a DU800 spectrophotometer (Beckman Coulter, Inc., CA, USA). BGL activity was expressed as the change in absorbance per minute per $\mathrm{mg} \mathrm{FW}(\Delta \mathrm{OD} / \mathrm{min} / \mathrm{mg} \mathrm{FW})$.

PPO activity was measured as the rate of formation of melaninlike material from phenolic substrates (Stout et al., 1998). Enzyme extract $(10-30 \mu \mathrm{L})$ was added to $1 \mathrm{~mL}$ of $2.92 \mathrm{mM}$ caffeic acid in $10 \mathrm{mM}$ Tris- $\mathrm{HCl}, \mathrm{pH} 8.0$, and $\Delta \mathrm{OD}$ was measured at $470 \mathrm{~nm}$ for $1 \mathrm{~min}$. PPO activity was expressed as $\Delta \mathrm{OD} / \mathrm{min} / \mathrm{g}$ FW.

For analysis of CDI activity, aspartic proteinase (pepsin) and its substrate biopodyl-labeled casein (BP-casein) were used as reported in a previous study (Christeller et al., 1998). Briefly, $100 \mu \mathrm{L}$ assay buffer (30 mM Tris-acetic acid, pH 2.0, containing $10 \mathrm{ng}$ pepsin) and $25 \mu \mathrm{L}$ enzyme extract or $25 \mu \mathrm{L}$ distilled water (as the control) were incubated in fluorometric tubes. The assay was initiated by addition of substrate $(0.5 \mu \mathrm{g}$ BP-casein), and the release of fluorescent peptide was detected by emission at $538 \mathrm{~nm}$. CDI activity was defined as the percent inhibition of pepsin activity (percent reduction in fluorescence emission) relative to the control.

PIs of plant extracts were assayed using the fluorometric method through detecting the degradation of the peptide substrate benzoyl tyrosine ethyl ester (BTEE) by the proteinase chymotrypsin (Stout et al., 1998). Briefly, enzyme extract $(25 \mu \mathrm{L})$ was added to $25 \mu \mathrm{L}$ of $1 \mathrm{mM} \mathrm{HCl}$ containing $1.5 \mu \mathrm{g}$ chymotrypsin. Following mixture, $2.9 \mathrm{~mL}$ of $0.5 \mathrm{mM}$ BTEE in $12: 13$ (v/v) methanol/Tris- $\mathrm{HCl}$ buffer, $\mathrm{pH}$ 8.0, was added, and the absorbance was monitored at $256 \mathrm{~nm}$ for $10 \mathrm{~min}$. For every sample run, a control was run without enzyme extract. PI activity was expressed as the percent inhibition of chymotrypsin relative to the control.

\subsection{Measurement of gene expression}

Total RNA was extracted from upper leaves and subjected to Northern blot analysis as described by Orozco-Cárdenas et al. (2001). Briefly, RNA $(30 \mu \mathrm{g})$ was electrophoresed on a 1.2\% [w/v] agarose gel with $0.67 \mathrm{M}$ formaldehyde. After separation, the RNA was transferred using 10×saline sodium citrate (SSC; $1.5 \mathrm{mM}$ $\mathrm{NaCl}, 150 \mathrm{mM}$ trisodium citrate) onto Hybond-N membrane (Amersham Pharmacia Biotech, Amersham, UK). The membrane was then incubated at $62^{\circ} \mathrm{C}$ for $2 \mathrm{~h}$ in prehybridization solution consisted of $10 \times$ Denhardt's solution ( $1 \%$ [w/v] polyvinylpyrrolidone, $1 \%[\mathrm{w} / \mathrm{v}]$ bovine serum albumin (BSA) fraction $\mathrm{V}, 1 \%[\mathrm{w} / \mathrm{v}]$ Ficoll 400), 3× SSC, 10\% dextran sulfate, 7\% sodium dodecyl sulfate and $167 \mu \mathrm{g} / \mathrm{mL}$ single-stranded salmon sperm DNA. Labeled gene probes were added to the prehybridization solution and blots were incubated for 18 to $36 \mathrm{~h}$ at $60{ }^{\circ} \mathrm{C}$. Hybridized membranes were treated with the Dig DNA Labeling and Detection Kit (cat. no. 1093 657, Roche Diagnostics GmbH, Mannheim, Germany). Equal mRNA loading was verified by 
hybridization with a labeled Actin cDNA fragment. Digoxigeninlabeled probes were generated from tomato cDNAs encoding PR-1, BGL-2, PIs, CDI and PPO (Orozco-Cárdenas et al., 2001) by random priming using the Dig DNA Labeling and Detection Kit according to manufacturer's recommendations.

\subsection{Statistical analysis}

The statistical analysis was performed using commercially available Statistical Product and Service Solutions (SPSS) software version 17.0 (SPSS; SPSS Inc., Chicago, IL, USA). Data gained from this study was expressed as mean \pm standard deviation (SD). Differences between different groups were compared using $t$ test. $\mathrm{P}<0.05$ considered indicative of a significant difference.

\section{Results}

\subsection{Induction of systemic $\mathrm{H}_{2} \mathrm{O}_{2}$ accumulation in tomato seedling leaves following cotton bollworm feeding}

Systemic levels of $\mathrm{H}_{2} \mathrm{O}_{2}$ were determined in the upper leaves of tomato seedlings at various time points ( 0 to $37 \mathrm{~h}$ ) at the start of bollworm feeding (Figure 1). In control plants (undamaged), the concentration of $\mathrm{H}_{2} \mathrm{O}_{2}$ remained at low levels over the entire period. In contrast, compared to the control, the $\mathrm{H}_{2} \mathrm{O}_{2}$ concentration in bollworm -damaged plants exhibited a significant elevation, and reached a peak of $0.84 \mu \mathrm{M} / \mathrm{g}$ FW at $12 \mathrm{~h}(\mathrm{P}<0.05)$. The concentrations of $\mathrm{H}_{2} \mathrm{O}_{2}$ in the upper leaves of DMTU- and DHC-treated seedlings that were challenged with cotton bollworms were slightly higher than those in the control, but they were much lower than those in non- cotton bollworm-exposed seedlings $(\mathrm{P}<0.05)$. Preliminary experiments showed that the scavenger DMTU or DHC alone did not affect insect feeding or normal seedling growth (data not shown).

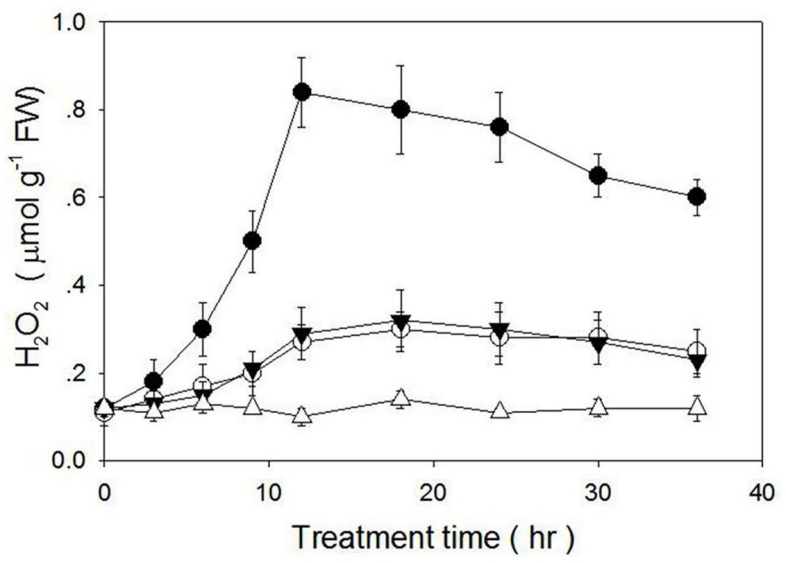

Figure 1. Induction of systemic $\mathrm{H}_{2} \mathrm{O}_{2}$ production in cotton bollworm feeding tomato seedlings. Samples were collected at the indicated time points, where time $=0 \mathrm{~h}$ corresponds to the onset of cotton bollworm feeding tomato leaves. Bollworms were removed when $80 \%$ of lower leaves were eaten $(-6 \mathrm{~h})$. For $\mathrm{H}_{2} \mathrm{O}_{2}$ scavenging, tomato seedlings were watered with DMTU $(0.1 \mathrm{mM})$ or DHC $(10 \mu \mathrm{M})$ daily for 3 days prior to cotton bollworm feeding and applied by spraying daily throughout the experimental period. $=$ cotton bollworm feeding; $\bigcirc=$ cotton bollworm feeding plus DMTU $(0.1 \mathrm{mM}) ; \boldsymbol{\nabla}=$ cotton bollworm feeding plus DHC $(10 \mu \mathrm{M}) ; \triangle=$ control (no bollworm or scavenger treatment). Data presented as mean $\pm \mathrm{SD}, \mathrm{n}=10$.
These findings suggest that insect feeding induced systemic accumulation of $\mathrm{H}_{2} \mathrm{O}_{2}$, and that this accumulation can be effectively reversed by $\mathrm{H}_{2} \mathrm{O}_{2}$ scavengers.

\subsection{Induction of defense-related enzyme activity following cotton bollworm feeding}

In upper leaves of undamaged tomato seedlings, the activities of PI, CDI, BGL and PPO all remained low over a 120 - to $150-\mathrm{h}$ period (Figures 2 and 3). Moreover, the upper leaves of bollwormdamaged seedlings exhibited the elevated activities of all four enzymes within $50 \mathrm{~h}$ from the start of bollworm feeding, and these levels remained high for the duration of the experiment in comparison with the control (Figures 2 and 3; $\mathrm{P}<0.05$ ). All increases in enzyme activities were substantially inhibited in bollworm-damaged seedlings treated with DMTU or DHC, indicating that $\mathrm{H}_{2} \mathrm{O}_{2}$ played an important role in the induction of defense-related enzyme activity. In the present study, DMTU and DHC alone did not influence the activities of these enzymes (data not shown).
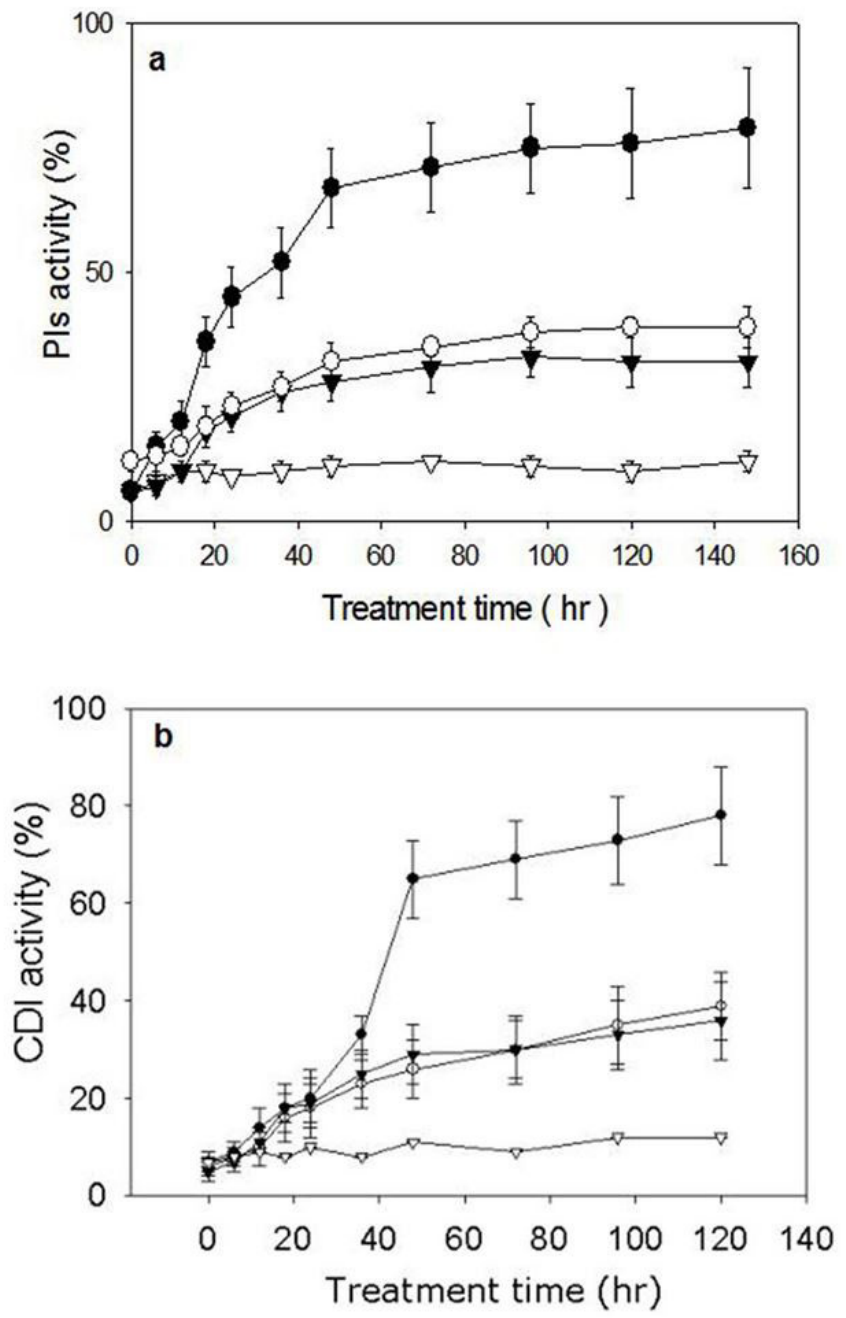

Figure 2. Induction of systemic increases in PI (a) and CDI (b) activity in cotton bollworm feeding tomato seedlings. $=$ cotton bollworm feeding; $\mathrm{O}=$ cotton bollworm feeding plus DMTU $(0.1 \mathrm{mM}) ; \boldsymbol{\nabla}=$ cotton bollworm feeding plus DHC $(10 \mu \mathrm{M}) ; \Delta=$ control (no bollworm or scavenger treatment). Data presented as mean $\pm \mathrm{SD}, \mathrm{n}=8$. 

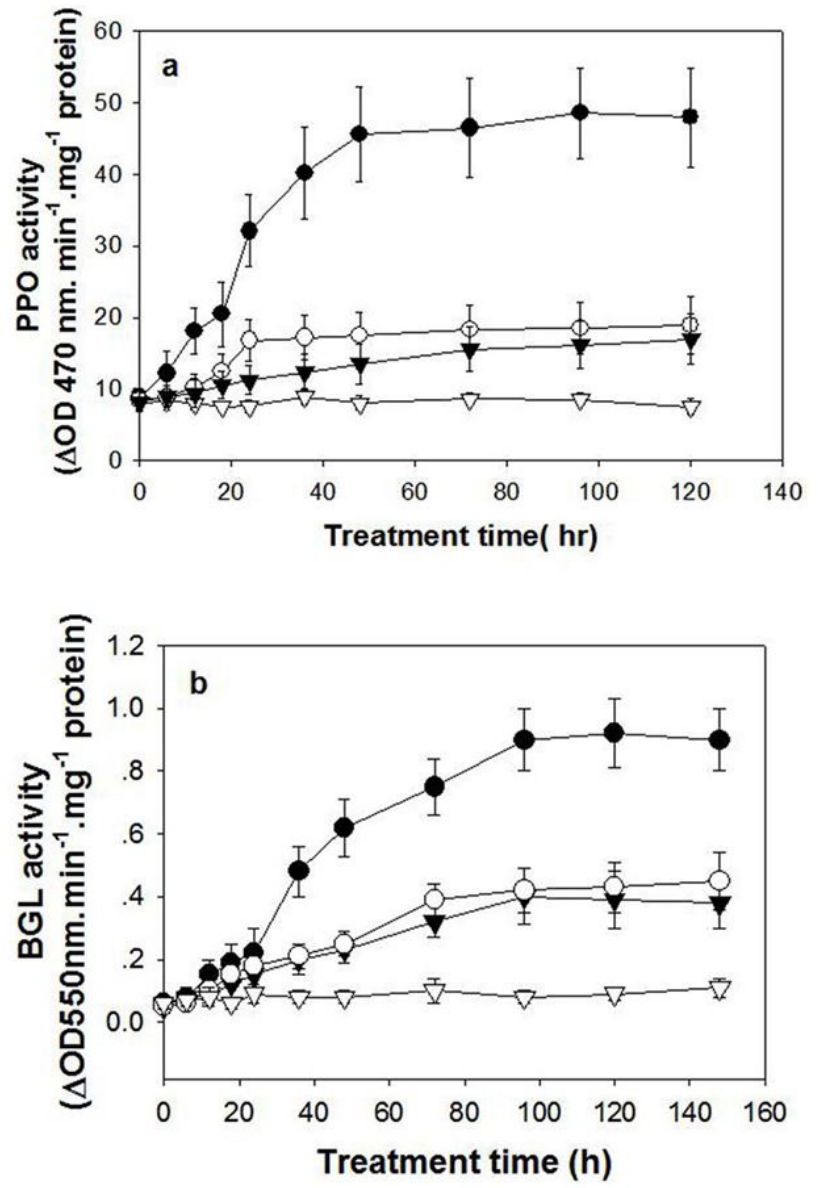

Figure 3. Induction of systemic increases in PPO and BGL activity in cotton bollworm feeding tomato seedlings. PPO (a) and BGL (b) activity were determined in cotton bollworm feeding, cotton bollworm feeding plus DMTU, cotton bollworm feeding plus DHC and the control groups. = cotton bollworm feeding; $\bigcirc=$ cotton bollworm feeding plus DMTU $(0.1 \mathrm{mM}) ; \boldsymbol{\nabla}=$ cotton bollworm feeding plus DHC $(10 \mu \mathrm{M})$; $\triangle=$ control (no bollworm or scavenger treatment). Data presented as mean $\pm \mathrm{SD}, \mathrm{n}=8$.

\subsection{Induction of defense-related gene expression following cotton bollworm feeding}

The upper leaves of undamaged tomato seedlings contained only very low amounts of PR-1, BGL-2, PI, CDI and PPO mRNA (Figure 4a). Compared to the control without damage, mRNA expression of PR-1, BGL-2, PI, and CDI in the upper leaves of bollworm-damaged seedlings was significantly promoted within $6 \mathrm{~h}$ of feeding. Increased expression of PPO was detected after $12 \mathrm{~h}$, and the highest expression was observed at $24 \mathrm{~h}$ (Figure 4a; $\mathrm{P}<0.05$ ). In the def-5 seedlings (which lack JA), mRNA expression of PR-1 (a product of the SA-dependent pathway) was found, but mRNA expression of PIs (products of the JA-dependent pathway) were not observed (Figure $4 \mathrm{~b}$ ). However, in transgenic $n a h G$ seedlings (which lack SA), PI expression was normal, and PR-1 expression was elevated (Figure 4b). Expression of these genes was suppressed to varying degrees by DMTU and DHC treatment (Figure 5), indicating a requirement for $\mathrm{H}_{2} \mathrm{O}_{2}$ in their activation.
Time (h) $\begin{array}{llllllll}0 & 3 & 6 & 9 & 12 & 24 & 48 & 96\end{array}$
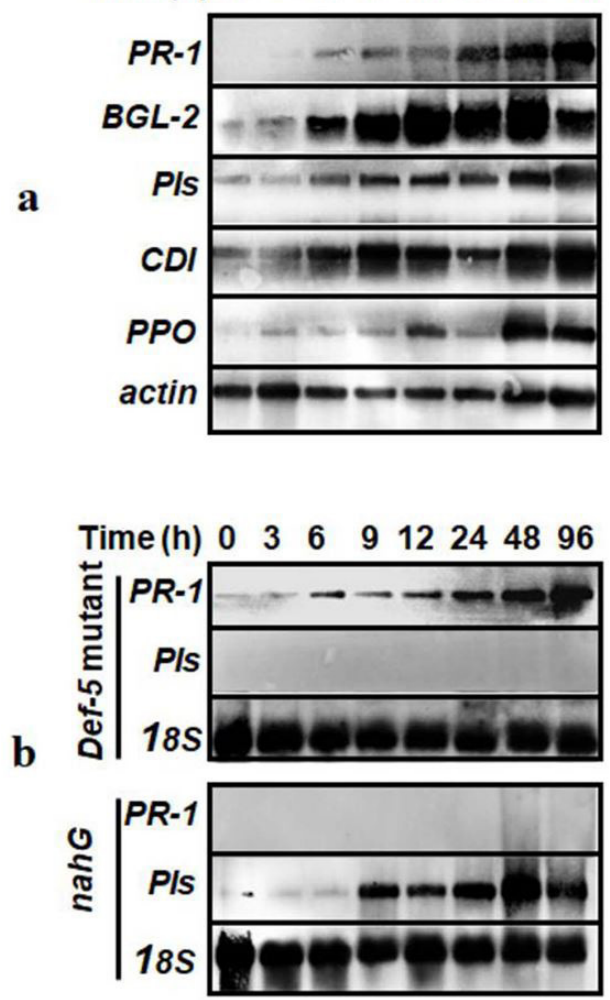

Figure 4. Expression of defense-related genes in tomato seedlings following cotton bollworm feeding. (a) mRNA expression of PR-1, BGL-2, CDI, PI and PPO genes in wild-type seedlings, and (b) PR-1 and PI genes in def-5 mutant and transgenic nah $G$ seedlings were detected by Northern blot. $\beta$-actin and $18 \mathrm{~S}$ were used as the loading controls.

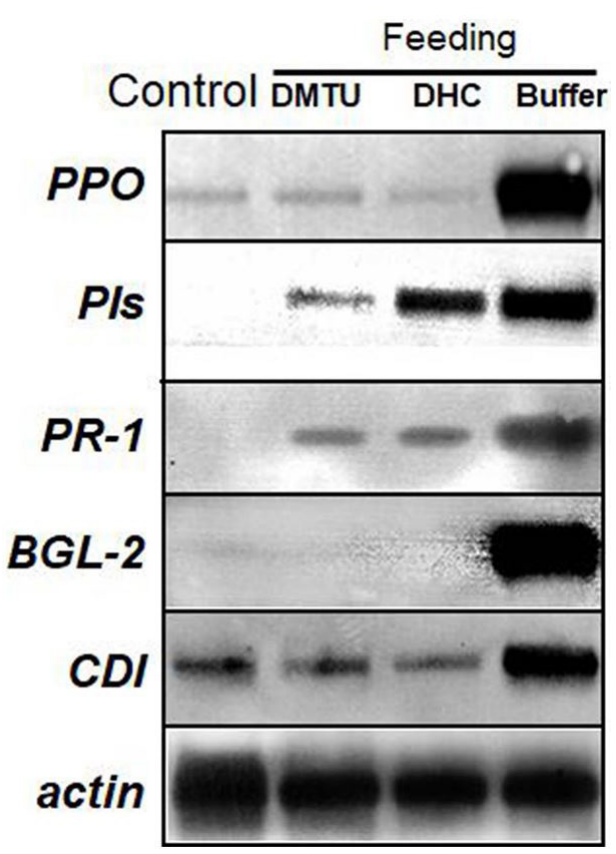

Figure 5. Effects of DMTU and DHC on expression of defense-related genes induced by cotton bollworm feeding. Tomato seedlings were treated with DMTU $(10 \mathrm{mM})$ or DHC $(10 \mu \mathrm{M})$ by daily watering for 3 days prior to cotton bollworm feeding. For the control, tomato seedlings were harvested without bollworm treatment. 


\section{Discussion}

Higher plants respond to insect attack and wounding by activating the expression of genes involved in herbivore deterrence, wound healing, and other defense-related processes. Defense responses occur at the site of wounding (local response) and in undamaged leaves located distal to the site of attack (systemic response) (Li et al., 2002). The wound response of tomato plants has been extensively studied and provides a useful model to understand the signal transduction events leading from injury to marker gene expression (Sun et al., 2011). Our results suggest that cotton bollworm feeding elicits a strong systemic defense response in tomato seedlings. Damage to the lower leaves by cotton bollworms causes an increase in the activities and mRNA expression of defense-related genes in the undamaged upper leaves, indicating that the effect was systemic.

PR-1 and BGL-2 are reporters of the SA-dependent pathway, which are normally involved in defense against pathogens. Moran \& Thompson (2001) reported that aphid feeding induces expression of PR-1 and BGL-2 (Moran \& Thompson 2001). Our data indicate that cotton bollworm feeding triggers the SA-dependent signaling pathway, since expression of the PR-1 gene is not induced in transgenic nah $G$ tomato seedlings. Our findings are consistent with previous findings that $\mathrm{H}_{2} \mathrm{O}_{2}$ does not function downstream of SA in the induction of PR protein expression (Bi et al., 1995). The role of JA and its methyl ester in plants damaged by wounding, pathogens or insects has been the focus of some studies (Stout et al., 1998; Ruuhola \& Yang, 2006). Herbivore feeding is suppressed in pre-wounded tomato leaves via the accumulation of PIs induced by JA (Schulze et al., 2019). In Arabidopsis, aphid feeding induces expression of an array of defense genes involved in the JA signaling pathway, although aphids do not activate the same intensity of JA signaling as wounding (Bi et al., 1995).

$\mathrm{H}_{2} \mathrm{O}_{2}$ acts as the second messenger for activation of PIs and the defense response in mesophyll cells of tomato plants (Orozco-Cárdenas et al., 2001). A previous study provided the evidence that damage to a single leaflet by mechanical wounding or insects results in local and systemic accumulation of defensive PIs within $2 \mathrm{~h}$ in tomato (Sun et al., 2011). Another study found that wound-inducible PIs in tomato plants provide a useful model system to elucidate the signal transduction pathways that regulate systemic defense response (Ryan, 2000). In our study, cotton bollworm feeding in upper leaves systemically induced higher expression of PI, CDI and PPO in lower leaves. In def-5 seedlings deficient in JA synthesis, cotton bollworm feeding do not increase the level of PIs. Thus, it is likely that cotton bollworm feeding induces the JA-dependent signaling pathway in tomato seedlings. Most reports indicate a mutually antagonistic interaction between SA- and JA-dependent signaling, such as the suppression by SA of the JA-dependent resistance of Arabidopsis to Egyptian cotton worm (Stotz et al., 2002). Our study found that cotton bollworm feeding activates both SA- and JA-dependent signaling. This is consistent with the findings of Moran and Thompson (Stout et al., 1998), which reported that these two pathways are also activated by aphid challenge in Arabidopsis.

There is evidence that the oxidative burst is a mechanism of plant resistance to pathogen infection and herbivore feeding
(Orozco-Cárdenas et al., 2001). $\mathrm{H}_{2} \mathrm{O}_{2}$ can damage insect digestive systems and suppress insect development. Feeding on previously wounded foliage results in oxidative damage to the insect midgut, and disrupts absorption and transport systems (Bi et al., 1995). Our results demonstrate that $\mathrm{H}_{2} \mathrm{O}_{2}$ levels rise sharply in the upper leaves of tomato plants in response to bollworm feeding on lower leaves. Whether $\mathrm{H}_{2} \mathrm{O}_{2}$ is transported systemically or is generated in the upper leaves in response to another systemic signal remains to be determined (Orozco-Cárdenas et al., 2001). $\mathrm{H}_{2} \mathrm{O}_{2}$ can act as a secondary messenger to induce wound or defense responses, as well as to upregulate the expression of a large number of genes (Orozco-Cárdenas et al., 2001; Levine et al., 1994). In this study, suppression of $\mathrm{H}_{2} \mathrm{O}_{2}$ with DMTU or DHC reduces the activity of CDI, BGL and PPO, the accumulation of PIs, and the expression of SA- and JA-dependent genes, demonstrating that $\mathrm{H}_{2} \mathrm{O}_{2}$ can mediate a variety of defense responses in bollworm-wounded tomato seedlings.

\section{Conclusion}

Taken together, our data indicate that $\mathrm{H}_{2} \mathrm{O}_{2}$ is an essential component of both JA- and SA-dependent systemic pathways involved in defense against cotton bollworm feeding tomato seedlings. Further understanding of the JA and SA signaling pathways promises to provide new insights into the basic mechanisms of plant defenses to wounding and insect stress.

\section{Acknowledgements}

This study was funded by The National Natural Science Foundation of China (31640006); the Major Projects of University Natural Science Research of Jiangsu Province (17KJA180002); the Huai'an Natural Science Research Project (HABZ201917) and Innovation and entrepreneurship training program of college students in Jiangsu (201910323029Y).

\section{References}

Agrawal, A., Rajamani, V., Reddy, V. S., Mukherjee, S. K., \& Bhatnagar, R. K. (2015). Transgenic plants over-expressing insect-specific microRNA acquire insecticidal activity against Helicoverpa armigera: an alternative to Bt-toxin technology. Transgenic Research, 24(5), 791801. http://dx.doi.org/10.1007/s11248-015-9880-x. PMid:25947089.

Argandoña, V. H., Chaman, M., Cardemil, L., Munoz, O., Zuniga, G. E., \& Corcuera, L. J. (2001). Ethylene production and peroxidase activity in aphid-infested barley. Journal of Chemical Ecology, 27(1), 53-68. http://dx.doi.org/10.1023/A:1005615932694. PMid:11382067.

Bi, Y. M., Kenton, P., Mur, L., Darby, R., \& Draper, J. (1995). Hydrogen peroxide does not function downstream of salicylic acid in the induction of PR protein expression. The Plant Journal, 8(2), 235-245. http:// dx.doi.org/10.1046/j.1365-313X.1995.08020235.x. PMid:7670505.

Browse, J. (2009). Jasmonate passes muster: a receptor and targets for the defense hormone. Annual Review of Plant Biology, 60(1), 183-205. http:// dx.doi.org/10.1146/annurev.arplant.043008.092007. PMid:19025383.

Chen, M. S. (2008). Inducible direct plant defense against insect herbivores: a review. Insect Science, 15(2), 101-114. http://dx.doi. org/10.1111/j.1744-7917.2008.00190.x.

Chen, Z., Silva, H., \& Klessig, D. F. (1993). Active oxygen species in the induction of plant systemic acquired resistance by salicylic acid. Science, 262(5141), 1883-1886. http://dx.doi.org/10.1126/ science.8266079. PMid:8266079. 
Christeller, J. T., Farley, P. C., Ramsay, R. J., Sullivan, P. A., \& Laing, W. A. (1998). Purification, characterization and cloning of an aspartic proteinase inhibitor from squash phloem exudate. European Journal of Biochemistry, 254(1), 160-167. http://dx.doi.org/10.1046/j.14321327.1998.2540160.x. PMid:9652409.

Ellis, C., Karafyllidis, I., \& Turner, J. G. (2002). Constitutive activation of jasmonate signaling in an Arabidopsis mutant correlates with enhanced resistance to Erysiphe cichoracearum, Pseudomonas syringae, and Myzus persicae. Molecular Plant-Microbe Interactions, 15(10), 1025-1030. http://dx.doi.org/10.1094/MPMI.2002.15.10.1025. PMid:12437300.

Erb, M., \& Reymond, P. (2019). Molecular interactions between plants and insect herbivores. Annual Review of Plant Biology, 70(1), 527557. http://dx.doi.org/10.1146/annurev-arplant-050718-095910. PMid:30786233.

Fan, R., Wang, H., Wang, Y. L., \& Yu, D. Y. (2012). Proteomic analysis of soybean defense response induced by cotton worm(prodenia litura,fabricius)feeding. Proteome Science, 10(1), 16-27. http://dx.doi. org/10.1186/1477-5956-10-16. PMid:22397523.

Fink, W., Liefland, M., \& Mendgen, K. (1988). Chitinases and $\beta-1,3-$ Glucanases in the apoplastic compartment of oat leaves (Avena sativa L.). Plant Physiology, 88(2), 270-275. http://dx.doi.org/10.1104/ pp.88.2.270. PMid:16666294.

Fürstenberg-Hägg, J., Zagrobelny, M., \& Bak, S. (2013). Plant defense against insect herbivores. International Journal of Molecular Sciences, 14(5), 10242-10297. http://dx.doi.org/10.3390/ijms140510242. PMid:23681010.

Grant, M., \& Lamb, C. (2006). Systemic immunity. Current Opinion in Plant Biology, 9(4), 414-420. http://dx.doi.org/10.1016/j. pbi.2006.05.013. PMid:16753329.

Koo, A. J., \& Howe, G. A. (2009). The wound hormone jasmonate. Phytochemistry, 70(13-14), 1571-1580. http://dx.doi.org/10.1016/j. phytochem.2009.07.018. PMid:19695649.

Levine, A., Tenhaken, R., Dixon, R., \& Lamb, C. (1994). H2O2 from the oxidative burst orchestrates the plant hypersensitive disease resistance response. Cell, 79(4), 583-593. http://dx.doi.org/10.1016/00928674(94)90544-4. PMid:7954825.

Li, L., Li, C., Lee, G. I., \& Howe, G. A. (2002). Distinct roles for jasmonate synthesis and action in the systemic wound response of tomato. Proceedings of the National Academy of Sciences of the United States of America, 99(9), 6416-6421. http://dx.doi.org/10.1073/ pnas.072072599. PMid:11959903.

Mason, C. J., Villari, C., Keefover-Ring, K., Jagemann, S., Zhu, J., Bonello, P., \& Raffa, K. F. (2017). Spatial and temporal components of induced plant responses in the context of herbivore life history and impact on host. Functional Ecology, 31(11), 2034-2050. http:// dx.doi.org/10.1111/1365-2435.12911.

Mayrose, M., Bonshtien, A., \& Sessa, G. (2004). LeMPK3 is a mitogenactivated protein kinase with dual specificity induced during tomato defense and wounding responses. The Journal of Biological Chemistry, 279(15), 14819-14827. http://dx.doi.org/10.1074/jbc.M313388200. PMid:14742423.

Mohase, L., \& Van der Westhuizen, A. J. (2002). Salicylic acid is involved in resistance responses in the Russian wheat aphid-wheat interaction. Journal of Plant Physiology, 159(6), 585-590. http:// dx.doi.org/10.1078/0176-1617-0633.

Moran, P. J., \& Thompson, G. A. (2001). Molecular responses to aphid feeding in Arabidopsis in relation to plant defense pathways. Plant Physiology, 125(2), 1074-1085. http://dx.doi.org/10.1104/ pp.125.2.1074. PMid:11161062.

Orozco-Cárdenas, M. L., Narvaez-Vasquez, J., \& Ryan, C. A. (2001). Hydrogen peroxide acts as a second messenger for the induction of defense genes in tomato plants in response to wounding, systemin, and methyl jasmonate. Plant Cell, 13(1), 179-191. PMid:11158538.

Qi, J., Malook, S. U., Shen, G., Gao, L., Zhang, C., Li, J., Zhang, J., Wang, L., \& Wu, J. (2018). Current understanding of maize and rice defense against insect herbivores. Plant Divers, 40(4), 189-195. http://dx.doi. org/10.1016/j.pld.2018.06.006. PMid:30740564.

Rasmann, S., \& Agrawal, A. A. (2009). Plant defense against herbivory: progress in identifying synergism, redundancy, and antagonism between resistance traits. Current Opinion in Plant Biology, 12(4), 473-478. http://dx.doi.org/10.1016/j.pbi.2009.05.005. PMid:19540153.

Ruuhola, T., \& Yang, S. (2006). Wound-induced oxidative responses in mountain birch leaves. Annali di Botanica, 97(1), 29-37. http:// dx.doi.org/10.1093/aob/mcj005. PMid:16254021.

Ryan, C. A. (2000). The systemin signaling pathway: differential activation of plant defensive genes. Biochimica et Biophysica Acta, 1477(1-2), 112-121. http://dx.doi.org/10.1016/S0167-4838(99)002691. PMid:10708853.

Schulze, E.-D., Beck, E., Buchmann, N., \& Clemens, S. (2019) Biotic stress. In E. D. Schulze, E. Beck, N. Buchmann, S. Clemens, K. Müller-Hohenstein \& M. Scherer-Lorenzen (Eds.), Plant ecology (pp. 257-299). Berlin: Springer. http://dx.doi.org/10.1007/978-3662-56233-8_8.

Sharma, P., Sharma, P., Arora, P., Verma, V., Khanna, K., Saini, P., \& Bhardwaj, R. (2019). Role and regulation of ROS and antioxidants as signaling molecules in response to abiotic stresses. In M. Iqbal, R. Khan, P. S. Reddy, A. Ferrante \& N. A. Khan (Eds.), Plant signaling molecules role and regulation under stressful environments (pp. 141-156). San Diego: Elsevier. http://dx.doi.org/10.1016/B978-0-12-816451-8.00008-3.

Shine, M. B., Xiao, X., Kachroo, P., \& Kachroo, A. (2019). Signaling mechanisms underlying systemic acquired resistance to microbial pathogens. Plant Science, 279, 81-86. http://dx.doi.org/10.1016/j. plantsci.2018.01.001. PMid:30709496.

Smith, J. L., Moraes, C. M., \& Mescher, M. C. (2009). Jasmonate- and salicylate-mediated plant defense responses to insect herbivores, pathogens and parasitic plants. Pest Management Science, 65(5), 497-503. http://dx.doi.org/10.1002/ps.1714. PMid:19206090.

Spoel, S. H., Koornneef, A., Claessens, S. M., Korzelius, J. P., Van Pelt, J. A., Mueller, M. J., Buchala, A. J., Métraux, J. P., Brown, R., Kazan, K., Van Loon, L. C., Dong, X., \& Pieterse, C. M. (2003). NPR1 modulates cross-talk between salicylate-and jasmonate-dependent defense pathways through a novel function in the cytosol. The Plant Cell, 15(3), 760-770. http://dx.doi.org/10.1105/tpc.009159. PMid:12615947.

Stotz, H. U., Koch, T., Biedermann, A., Weniger, K., Boland, W., \& Mitchell-Olds, T. (2002). Evidence for regulation of resistance in Arabidopsis to Egyptian cotton worm by salicylic and jasmonic acid signaling pathways. Planta, 214(4), 648-652. http://dx.doi. org/10.1007/s004250100656. PMid:11925049.

Stout, M. J., Workman, K. V., Bostock, R. M., \& Duffey, S. S. (1998). Stimulation and attenuation of induced resistance by elicitors and inhibitors of chemical induction in tomato (Lycopersicon esculentum) foliage. Entomologia Experimentalis et Applicata, 86(3), 267-279. http://dx.doi.org/10.1046/j.1570-7458.1998.00289.x.

Sun, J. Q., Jiang, H. L., \& Li, C. Y. (2011). Systemin/Jasmonate-mediated systemic defense signaling in tomato. Molecular Plant, 4(4), 607-615. http://dx.doi.org/10.1093/mp/ssr008. PMid:21357647.

Tholl, D., Sohrabi, R., Huh, J. H., \& Lee, S. (2011). The biochemistry of homoterpenes: common constituents of floral and herbivore-induced plant volatile bouquets. Phytochemistry, 72(13), 1635-1646. http:// dx.doi.org/10.1016/j.phytochem.2011.01.019. PMid:21334702.

War, A. R., Paulraj, M. G., Ahmad, T., Buhroo, A. A., Hussain, B., Ignacimuthu, S., \& Sharma, H. C. (2012). Mechanisms 
of plant defense against insect herbivores. Plant Signaling \& Behavior, 7(10), 1306-1320. http://dx.doi.org/10.4161/psb.21663. PMid:22895106.

Waterman, J. M., Cazzonelli, C. I., Hartley, S. E., \& Johnson, S. N. (2019). Simulated herbivory: the key to disentangling plant defence responses. Trends in Ecology \& Evolution, 34(5), 447-458. http:// dx.doi.org/10.1016/j.tree.2019.01.008. PMid:30824196.
Zhu-Salzman, K., Bi, J. L., \& Liu, T. X. (2005). Molecular strategies of plant defense and insect counter-defense. Insect Science, 12(1), 3-15. http://dx.doi.org/10.1111/j.1672-9609.2005.00002.x.

Zurbriggen, M. D., Carrillo, N., \& Hajirezaei, M. R. (2010). ROS signaling in the hypersensitive response: when, where and what for? Plant Signaling \& Behavior, 5(4), 393-396. http://dx.doi.org/10.4161/ psb.5.4.10793. PMid:20383072. 